\title{
MYH2 Gene
}

National Cancer Institute

\section{Source}

National Cancer Institute. MYH2 Gene. NCI Thesaurus. Code C112133.

This gene is involved in skeletal muscle contraction. 